\title{
PARA UM ESTUDO DA REALIDADE SIMBÓLICA NA POESIA DE HERBERTO HELDER
}

\author{
JOÃO DÉCIO \\ (Professor da Faculdade de Filosofia, Ciências e \\ Letras de Marilia) \\ R E S U M O
}

No breve ensaio que dedlquei ao estudo da poesia de Herberto Helder procurei fixar especialmente os processos criadores, em particular os ligados à problemática da metáfora e do símbolo.

Naturalmente tal abordagem levaria a caracterizar a linguagem poética do autor de Oficio Cantante, que revela uma dimensāo em muitos momentos nova e renovadora.

Além da realidade metafórica e simbólica, procurei assinalar a constante recorrência aos aspectos da natureza, como a flor, o fruto, o sol, a lua que conferem à poesia um caráter elemental num constante apelo à volta às origens.

Associados ao caráter simbólico e metafórico, procurel detectar os elementos plásticos e sensoriais da poesia de Herberto Helder que começam a substituir Irresistivelmente o pensar, permanecendo o sentimento constantemente associado àquelas vivências.

Procurei apontar outros processos poéticos como a anáfora e a intensificaçäo, bem como a preocupação em toda linha com a metalinguagem e com a organizaçāo de uma teorla poética.

Da parca bibliografia existente sobre o poeta, aproveitei para redimensionar dois artigos que publiquei sobre o assunto. Da mesma forma foram consultados os trabalhos que Maria Lúcia Lepecki e Ruy Bello publicaram 
respectivamente na revista Vozes $n .^{\circ} 4$ e no livro, na Senda da Poesia. Nāo havia ainda tido acesso às páginas que Antônio Ramos Rosa dedicou a Herberto Helder em Poesia, Liberdade Livre o que só pude fazer posteriormente à redaçāo do ensaio.

Finalmente, aqui e ali procurei assinalar as caracteristicas da poesia de Herberto Helder que o tornam um dos poetas mais originais e curiosos da atual Literatura Portuguesa.

\section{II - INTRODUÇAO}

São vários os caminhos pelos quais a Ciência Literária tem tentado. através dos tempos, apreender a essência do fenômeno literário. Essa diversidade de métodos critico-literários justifica-se pela própria natureza do objeto literário - expressão não univoca do homem e do mundo. De fato, cada época tem tido seus modos pecullares de apreendē-lo, o que faz surgir entāo, a cada tempo, uma nova expressāo literária, um novo expoente de comunlcabllidade artística.

Neste trabalho pretendemos, mais uma vez, ressaltar essa evidência dentro de um contexto rico em peculiaridades sobre a natureza do objeto literário, que são os poemas de Herberto Helder. Nossa escolha verteu-se subre este poeta porque ele está entre nós, vive nosso mundo, sente os problemas do homem moderno. Herberto Helder, a nosso ver, sabe mais que ninguém, transformar o quotidiano e tudo que o e nos cerca em poesia, em comunicação total para os sentidos.

Para compreendermos a obra de Herberto Helder "precisamos nos sltuar na fronteira de duas realidades: de um lado, as palavras com que vivemos quotidianamente, isto é, com que gastamos o tempo, com que duramos; de outro lado, as mesmas palavras, mas, utilizadas de modo que se propõem ser a metáfora das outras, construindo uma realidade simbólica e irrepetivel: como se estivéssemos em face de uma língua nova que é o eco da que conhecemos, enigmática mas apelativa, fascinante mas aterradora" (1). Eis, entăo, no que jaz nossa proposição: uma tentativa de desvendar os mistérios dessa "linguagem-fenômeno" de Herberto Helder, através da exploração de suas metáforas e antíteses.

(1) Fernando mendonça - A Literatura Portuguesa no Séeulo XX, Hicitec, Sĩo Paulo. 1973, p. 214.

A fim de alcançarmos nossa proposiçāo, não nos prenderemos a qualquer corrente crítico-literária, porque nāo é fácil justificar ou enquadrar um texto de Herberto Helder neste ou naquele conceito. Surrealista? Para alguns. Poeta maior? Para todos. E, os que o conhecem e à sua obra, sabem como ele caminha numa selva de temas e imagens plurais, multiplicáveis, às vezes inacessiveis.

Toda nossa pesquisa e as citaçōes que se fizerem neste trabalho, acerca dos poemas de Herberto Helder, serão tirados dos volumes I e II de POESIA 
TODA (1), que reúnem a produçăo poética desse autor entre 1953 e 1972.

A - Breve estudo sobre METAFORA.

A fim de nos situarmos no estudo a que nos propusemos - A REALIDADE SIMBOLICA EM HERBERTO HELDER - é necessário que nos detenhamos um pouco mais no estudo das figuras de palavras ou tropos.

A1 - Segundo PIERRE GUIRAUD, pelo nome de figura designa-se "uma maneira de falar mais viva que a llnguagem comum e destinada a tornar sensivel a idéia por meio de uma imagem, uma comparação ou a chamar melhor a atençāo pela sua justeza ou originalidade. As figuras constituem a base de uma teoria do ornamento." (2)

A2 - WOLFGANG KAISER designa como princlpal figura a METAFORA. Para esse autor, metáfora quer dizer transposiçăo: o significado de uma palavra é usado num sentido que the não pertence inicialmente. Diz ainda, que, a metáfora, é um dos meios mais eficazes para a ampliaçāo do âmbito de significado e para pôr em movimento aquele que entra nele. Ao mesmo tempo, é precisamente pela metäfora que se torna claro não possuirem as palavras só o seu respectivo significado, mas ainda, energias sugestivas. valores sociais, idéias de todo o gênero. A interpretaçăo estilística tem de analisar para onde é que o poeta quer nos conduzir através da metáfora $\theta$ que funções ela exerce em cada caso, a tem ainda de estudar a conexão. a atuação em conjunto das diferentes metáforas.

(1) HeRberto helder - POEsia TODAI II - Plitano Editora, Lisbon, 1973.

(2) Pierre guiraud - A Estilistica - Ed. Mestre Jou. S.P. pp. 30-31.

A3 - Dentre os vários estudos sobre metáfora a que nos estamos detendo, buscamos as palavras de JOHN MIDLETON MURRY no seu conhecido ensaio "METAPHOR". Observou esse autor, que "intentar um exame fundamental da metáfora (na obra literárì), importaria em nada menos do que uma investigaçāo da gênese do próprio pensamento - uma arriscada empresa." (3) Por sua vez CROCE completa: "Por que impor-se este incômodo de usar uma palavra em lugar da palavra própria quando temos esta última? Se, por outro lado, a palavra própria näo existe em caso particular. isto quer dizer que a metáfora é ela mesma a palavra da qual a gente havia pretendido distingui-la" (4)

(3) Cit. in OSWALDINO MARQUES - ENSAIOS ESCOLIIDOS - (Teoria e Critica Literárias) - Civllizaçấo Braslleira.

A4 - Ainda em citaçōes de estudlosos sobre o assunto, vamos encontrar em ARISTOTELES, pai da lógica, uma sua definiçăo sobre a metáfora: "a transposiçăo a uma coisa do nome de outra coisa, efetuando-se ou do 
gênero à espécie, ou da espécie ao gênero, ou da espécie à espécle, ou, finalmente por analogia". E mais - "ajuntar, em lugar do que se fala, aquilo a que a gente se refere". (5)

A5 - Mais modernamente, CASSIRER classifica as metáforas em duas espécie: metáforas miticas e lingüisticas. Essa última seria uma espécie de sucessão da parte pelo todo, constituindo um dos elos primordiais que leva. ria ao mito.

A6 - AUSTIN WARREN e RENE WELLEK, vêem os tropos como configurados pela convergência de duas linhas. Uma, o continuum sensorial a estético que liga a poesia à música e à pintura, e a distância da filosofia e da ciência. Outra, a figuraçāo ou tropologia, isto é, o discurso oblíquo, que tem como instrumentos a metonimia e a metáfora, parcialmente comparando mundos e precisando os seus temas. Em determinada fase de seus estudos, eles apontam como ingredientes básicos da metáfora, a analogia, dupla visāo. imagem sensorial e projeção animistica. Esses mesmos termos não aparecem em proporção Igual; delimitam-se de época para época, lugar para lugar e de periodo estético para periodo estético.

A7 - O grupo de estudiosos que faz parte da corrente MEANING (WINKLER, CROCE, RICHARDS e o lingūista sueco GUSTAV STERN) enquadra o mecanismo metafórico no processo comum de denominação. No entanto, vários outros estudiosos como Wundt, Konrad... não são desta mesma opinião e atribuem autonomia quase total à metáfora estética em oposição à metáfora lingüistica, isto $e$, enquanto essa realça atributos de determinados objetos em face de cutros circundantes, aquela (metáfora estética), deflagra em nós uma impressão nova do objeto.

\section{(4) IDEMI}

(b) IBIDEM

(6) BENEDETTO CROCE - A POEsIA - Introduçio a Critica e Histária da Poesia c da Literatura - Ediçues da Faculdade de Filosofia da Univergidade Federal do Rio Grancte do sul - Porto Alexre - $196 \hat{\text {. }}$

(7) Herberto Helder, nascido em 1930 em Funchal, Ilha da Madeira, é jornalista. Iniciau sua carreira poética em 1958, quando publicou AMOR EM VISITA. Pertence no grupo de poetas do movimento "Poesis 61" e foi co-organizador de POESIA EXPERIMENTAL I E II: participou de "Visopoemas" - exposiçīo coletiva experimenta] realizadn na Galeriu Divulgaçāo, em Lisbon, em 1965. Suns obras publicadas: Poesia - OFICIO CANTANTE (poemas de 1958 ate 1967): RETRATO EM MOVIMENTO (1967) VOCAÇÃO ANIMAL (1971): O BEBEDOR NOTURNO (1968) - verböes de poesias e POESIA TODA I e II (1973). Prosa - OS PASSOS EM VOLTA (1963): APRESENTAÇ̃̃o DO ROSTO (195S)' - tir. O ESTADO DE SAOO PAULO - Suplemento Literürio - "Oficio de Dizer" - Marin Lúcia Lepecki $30 / 12 / 73$.

A8 - Para J. A. RICHARDS, semanticista. psicólogo e teórico inglès autor de THE MEANING OF MEANING, há três elementos em toda metáfora: $10^{\circ}$ - o referente: 0 objeto da analogia. 
2. - o análogo: a coisa a que o referente se prende por analogla.

3. - o continuum: a faixa de similitude, real ou mental, que permite a analogia.

Para Richards, o pensamento procede por comparação e só tem sentido dentro do contexto a que pertence.

A9 - A autora HEDWIG KONRAD, por sua vez, acentua que pelo menos para os substantivos a metáfora constitul um cruzamento entre os dois modos de classificaçāo, porquanto, sobre reunir dois objetos em virtude de um traço comum, os subordina a um gênero superior que compreende todas as espécies possuinda a mesma estrutura. Os verbos e adjetivos, porém, estariam fora desse enquadramento, visto como, sendo simples os conceltos de ação e de atributo, não pode haver para eles uma classificaçāo fundada em elementos isolados. Quando se diz que um pêndulo marcha, o movimento respectivo é apenas uma nova espécie de marcha em geral.

B - SINESTESIA: ponte para o estudo poético.

Da metáfora, passa-se facilmente à chamada SINESTESIA: efeitos imagéticos decorrentes da traduçāo de um sentido por outro, por exemplo, a interpretaçāo de cores por sons, sensaçōes olfativas projetadas num nível tátil, sensações gustativas sugeridas por impressões térmicas, etc. A pesquisa das permutas sinestésicas (transferts) é um dos recursos mais estimados pela crítica moderna para revelar a amplitude da imaginação do poeta e o grau de originalidade de suas percepções.

Em se falando de percepções, é-nos urgente conceituarmos estas mesmas percepções do poeta como elas aparecem, em que intensidade nos atingem e como denomlná-las. Digamos que se denominem POESIA.

Dentre os muitos conceitos que lhe são atribuidos, o que mais nos prendeu a atençāo foi o de um homem que vibrou com a vida, com a violência e o amor: William Shakespeare. Definiu-a como uma "espécie de magia na qual o poeta, volvendo os olhos da terra ao céu e do céu à terra, atribul figura, lugar e nome a nadas aéreos" (ou sinestésicos...), e recomendou aos artistas "não o desafogo na violência, mas a temperance e a smoothness, ainda que em meio à tempestade e ao torvelinho dos afetos." (6)

Benedetto Croce é categórico ao afirmar que precisamos nos conscientizar das falsas estéticas que conceituam poesla: a intelectualista que a confunde com a prosa literárla; a sentimentalista que confunde com o sentimento ou com a expressāo literária do sentimento; a pragmática que a confunde com a expressāo literária da oratória; a hedonista que a confunde com a literatura amena; $e$, por último, a formalista que a confunde com os diletantismos da arte pela arte. Ela $\hat{\epsilon}$, antes, a "sugestão" que atinge a nós leitores, fazendo-nos entender os sons e formar imagens do que nos rodeia, como melhor nos aprouver. Logo, a poesia é Independente do poeta. Este é apenas um veículo transmissor de estímulos e Imagens que visam atingir o Universo individual de cada leltor. Dentro desse Universo, a poesia é um 
contínuo renascer, reevocar, segundo cada individuo, segundo sua vontade, sua aceitação ou não à palavra poética. Eis, entāo, outro grande problema a ser discutido, mas, por năo ser de nosso interesse nesse tópico, deixá-lo-emos passar. No entanto, vem a nós a conclusão de que poesia é aceitação de uma contemplaçāo já vivida.

As palavras, para a poesia, nāo sāo belas ou feias, aceitáveis ou não. desde que estejam em seu lugar próprio e atinjam seu receptor, encaixando-se em suas experiências e voliçōes. Essa, então, é a verdadeira poesia. Não há desmembramento poeta-leitor, e sim, uma simbiose que visa ampliar certa comunicação, não baseada em termos pré-estabelecidos ou padronizados.

(8) JOÄO DECIO - Introduçāo zo Estudo da Poesis de Herberto Helder - Revista Alfa, 17, Depto. de Letras, FAFi Marilia, 1971.

(9) Cit. in HeIDEgGer - "Holderlin und ờas Wesen der Dichtung". (ensaio), Munique.

\section{III - REVISAO dA BIBLIOGRAFIA CRITICA EM tORNO}

\section{DE HERBERTO HELDER}

A - Características primeiras da obra de Herberto Helder (i).

A obra de Herberto Helder é comunicante porque é real, viva, atual; intensa porque é vinculada a sensaçōes físicas e eróticas que englobam uma grande vivência lírica e dramática em torno do ser e para o ser. Em Herberto Helder "há uma preocupaçăo de construir a poesia e construir uma linguagem". ( $\left.{ }^{(}\right)$

Partindo dessa proposiçāo, muitos criticos já disseram que Herberto é um poeta de dificil leitura. Poremos em debate esse tópico, uma vez que a obra foética é um constante renovar. Nāo importa se as palavras já foram mil vezes repetidas, $s e$ as imagens que cada poema transmite jă foram perpassadas por outras mil interpretaçōes, em tantas outras obras de tantos outros autores já analisados por este ou aquele critico. A base vital de uma obra literária, seja ela poesia ou prosa, reside no fato da intenção imposta pelo autor ao transportá-la em linguagem, e, ainda no fato do leitor sentir essa intenção/linguagem.

Pois bem, Herberto Helder é mais um autor, sua obra é mais um "amontoado" de imagens, sons e sensaçōes que cada um de nós teremos que desvendar e sentir conforme nossas experiências e vontades. $O$ dinamismo, 0 sonho, a vida, o caos, a morte, a apatia, o desejo, o amor, são as constantes preocupaçōes de Herberto Helder. Para nós está sendo muito importante esse sentimento de encontro e comunhảo que nasce a cada leitura de um poema desse autor. A cada momento vislumbramos algo novo que, como uma corrente, nos remete à palavra seguinte e nos recorda um poema já lido. O poeta está preocupado todo o tempo em nos dizer sobre sua vida, o que o rodeia ou o que deseja. Para atingirmos, então parte de sua mensagem, vamos partir de símbolos (ou metáforas...) que ele nos apresenta em forma 
de poemas. Vamos sim, tomar uma linha diretriz temática para nos situarmos em nossas reflexōes, porque "poetar é a mais inocente das ocupaçōes; poetar é uma forma de Jogo; poetar é além disso, uma atividade ineficiente; poetar é falar por falar; dizer por dizer, isto é, linguagem pura. Mas, a pa lavra 6 o mais perigoso dos bens. $O$ homem tem de a utilizar para testemunhar o que é. Ao lançar mão dela, expõe-se, ao seu ser, põe-no a descoberto e arrisca-o". (')

Assim fazendo, Herberto Helder poeta, não esconde colsa alguma, é evidente demais a ponto de nos desnortear e fazer-nos precaver contra tāo aparente evidêncla." As palavras podem funcionar como metáfora uma das outras, de qualquer maneira, serão sujeitas à ação do contexto". (10) Quando o poeta fala em amor, sua poesia năo é só, ou é colsa diferente de poesia de amor; que a mulher pode não ser ela mesma, porque, a cada instante, o poeta parte de uma emoçāo nova que irá "transfigurar" a emoçāo ou experiência anterior.

(10) RUY BELO - NA SENDA POEsia.

(11) IDEM

(12) POESIA TODA I - a Colher na Boca, 1953-1960 - "Prefácio", p. 11

(13) POESIA TODA 1 - Poemacto, 1961 - "II" p. 128

(14) POESIA TODA I - Lugar, 1961-1962 - "Teoria Sentada", p. 188

Em nossas leituras "de/vagar", como nos manda o próprio Helder, sobre seus poemas, vimos que o poeta, através dos símbolos e metáforas que usa, quer chegar, não a conclusōes ou mesmo deduçōes, mas sim, a alcançar a algo que está acima de sua visāo, às vezes de sua aceitação, o que denominaremos vislumbre da eternidade.

Cabe-nos explicar, no entanto, que essa nossa proposiçāo não será apoiada em bases filosóficas ou psicológicas, mas sim, no que a poeta nos oferece em cada poema seu. Rul Belo visualiza este tópico nāo completamente e o chama de "luta pela eternização Impossivel do momento". [11]

\section{IV - A REALIdAde SIMBÓlica EM HERBERTO HELDER}

\section{A - Proposiçōes}

Muito se diz, e ainda há por dizer sobre uma tendència, que já é presença constante em muitos poetas atuais, que é a reduçăo vocabular, ou, o "enxugamento" da palavra. No entanto, forma-se um paradoxo muito grande ao confrontarmos essa tendência com uma outra que se cria paralela: a busca da comunicaçăo, o sentido de uma procura de manifestação do Humano e das coisas na sua realidade primeira.

Logo, está criado à primeira vista, o paradoxo. Para se comunicar e chegar à sua essência o homem precisa dialogar, usar palavras. Por outro lado, o homem chegou a uma outra realidade; a palavra desgastou-se (?). Pois bem. este desgaste da palavra do dia-a-dia levou-o a selecionar as palavras, a condensar o discurso $\theta$ dar às palavras um caráter inotativo, isto $e$, a palavra se desdobra em outra, tornando-se, por sua vez a palavra poética. 
Ao ver a séria ameaça que sofre a dualidade: significado-significante, principalmente o poeta, condensa o discurso, enxuga as palavras. Herberto Helder: se analisarmos sua obra por este prisma, veremos que já fez sua seleção. A repetição de determinadas palavras em seus poemas: mulher, amor, poema, primavera, estrela, campos, noite, cançōes, flores, filhos, Deus, silêncio, fonte, luz, palavras, obra, mundo, vida, pedra, inspiraçāo, amigo. sofrimento. coraçāo. pecado, ảgua, sexo, amoras, sangue, relâmpago, carne, morte... vão nos propiciar certas imagens e, mesmo situaçōes, que sāo frutos próprios da junção destas palavras. Ou, antiteses como claro - escuro (luz, noite); morte - vida (morte, vida, coraçāo...); frio - quente (água, sangue, fogo...); ruido - silêncio (canção, vento, palavra, pedra, silêncio): amor vlolêncla - amor ternura (sexo, coxa, mulher, filhos, flores, sofrimento,...).

Deste minimo, vamos determinar nossas reflexōes acerca da obra de Herberto Helder. De seus muitos poemas, aliás, poderiamos dizer a maioria deles, é de aspecto discursivo e até mesmo, exaustivos. Mas, se voltarmos ao que dissemos no início desta nossa proposição, veremos que essa discursividade é aparente, uma vez que em cada poema há sempre a repetiçāo das mesmas palavras, apenas criando novas imagens e novas sensa. çöes.

"Falemos de casas, do sagaz exercicio de um poder tāo

firme e silencioso como só houve

no tempo mais antigo" (12)

"- Era uma casa - como direi? - Absoluta" (13)

"... (crendo) só no antigo gesto que alarga a solidão" (14)

As palavras vão-se sucedendo num contínuo, até que o poeta se perde em sensações emanadas pelas imagens visualizadas e pelas sonhadas.

"Tudo o que é como um sinal fecundo

da terra, tudo o que se toca entre

comoçāo e pensamento.

deve participar do vosso cântico, ó

corpos apoteóticos, corpos

reconstruidos sobre 0 frio ascético dos cadáveres

Eu canto as vossas coxas verdes; o antigo turbilhonar do Instinto..." [10]

(15) POESIA TODA I - A Colher na Boca, 1953-1960 - "Ciclo" p. 17.

Eis as imagens sonhadas, sublimadas pelo tratamento na 2." pessoa do plural com que a elas o poeta se refere - vossas, vosso.

Nitidamente percebemos que o poeta năo fala com seres reais neste poema. O poeta evoca e é evocado; deixa-se envolver pelas apelaçōes e chamamentos. E' um poema de reverências: o poeta se reverencia perante 
alguma colsa que the é perceptivel, sensivel, mas que năo se the aparece de forma palpável. E-lhe perceptível através do que o rodeia como: fome, mesa, erva virgem. água, aragem, polen, fruto, lua. $O$ é também através de sonhos que o poeta transporta ao poema em forma de oxímoros - bela ferocidade, coxas verdes, ventre dlurno... Faz-se ora então transportarmos as palavras creditadas de Fernando Mendonça aqui: "nāo fora o Surrealismo e a sua corajosa experiência verbal, não teriamos possivelmente poetas capazes de dar às palavras as bocas pelas quais elas falam agora. Ao nivel das imagens liberadas e do metaforismo refratado de um Herberto Helder é, sem dúvlda, a colheita do Surrealismo que vemos amontoar. ${ }^{16}$ ] (16) Fernando mendonga - A Literatura Portugaesa no Século XX - Hicitec,

São Paulo, 1978.

B - Do Levantamento à Análise.

E tempo de pormos à baila nossas reflexões acerca da obra de Herberto Helder. $E$ é tempo também de crermos no ideal poético; na força que cada um traz dentro de si a as várlas maneiras que cada um de nós lança mãos para extravasá-la. Herberto Helder lançou-se à POESIA.

\section{1 - Do Sonho}

Como diz André Breton, o homem é um sonhador definitivo e, que a maior liberdade (ou única ...) que tem, é a do espírito. Além disso, Breton ainda exalta no homem, a imaginação, a qual nāo perdoa. Dito isto, logo voltamos à evidência de que, com razão, o homem é fruto de sua próprla imaginaçāo. E dela que ele vai extrair seu "modus vivendi". E para cultivála que vai criar-se e recriar o que o cerca até encontrar sua satisfação ou, então, viver à busca dessa satisfação. Ela, uma vez não encontrada no que o rodeia, o homem passa a sonhar, criar uma realldade supra que chega a superpor a vida onírica à real.

"A minha idade é assim - verde, sentada

Tocando para baixo as raizes da eternidade

Um grande número de meses sem multes saídas

soando

estreitos sinos, mudando em cores mergulhadas

A minha idade espera, enquanto abre

os seus candeoiros. Idade

de uma voracidade masculina.

Cega.

Parada.

Algumas mãos fixam-se à sua volta." (17)

(17) POESIA TODA 1 - Lugar, 1961-1962 - "Teoria Sentada" - p. 194.

As vezes, deixamos de ler um poema justamente porque não o entendemos. Esta é a mesma razão porque um autor é ou năo conhecido. Acima está um pequenino trecho de um poema de Herberto Helder. Săo reflexōes de un homem acerca de sua Idade, como ele a vê ou vive. Não há preocupaçăo do poeta em dizer sobre sua Idade como o resto do mundo gostaria 
de ouvi-lo dizer. Palavras como verde, sentada, cores mergulhadas, candeeiros, voracidade masculina, cega... não criam imagem próprỉa conotante com idade, que é o motivo a que o poeta se refere.

O poeta, descrevendo sobre sua idade através de imagens não conexas, partiu para um mundo onde só ele domina.

Escolhemos esta primeira estrofe porque ela 6 o próprio poema, porque parte de uma definição - A minha idade é assim - As imagens que se seguem em todo o poema como testemunhas de defesa do poeta contra o processo do mundo excessivamente real que o cerca, o seu não conformismo com o passar do tempo e sua inutilidade de homem limitado. Daí sua idade ser cega, parada. Por outro lado, quando ele mesmo pára e pressente como é sua idade interior, ou como ele a cria dentro de si moldando-a com a força suprema de sua imaginaçāo, a "idade espera enquanto abre os seus candeeiros./ Idade de uma voracidade masculina". O poeta, para si, encontra o caminho da vivência: a sua idade năo está parada quanto parece, ela llumina e é dinàmica, ela toca "para baixo as raizes da eternidade". Ao fim do poema o poeta mesmo val esclarecer o que dissemos sobre sua idade aparente e sua idade interior.

"Oue (idade) imita por um lado

as naçōes celestes. Que imita

por um lado a terra

quente". (1s)

O poeta, no seu processo de divagaçăo onírica, faz de sua idade um instrumento de luta $e$ força criativa; d́-lhe animismo, transforma-se todo nela, dinamiza-se, mostra-se. A idade a tudo abrange, é o próprio ser poético. E como se todo ele vibrasse coerente com as emanaçōes do mundo, uma vez que se liga à natureza, (verde, raiz, luz, folhas, pedra, noite, rosa, ar. águas, terra) aos seres. Aqui abrimos um parêntese para um aspecto muito interessante dentro da poesia de Herberto Helder: a ocupação do espaço por um corpo ou partes do corpo. Mesmo para o mundo onírico, isto também é um processo de comunicação. Há uma preocupaçāo de conhecimento do corpo humano. No momento em que o ser puder atingir um espaço ilimitado, comunicar-se com tudo e todos atlngirá a eternidade. Este é o ideal poético Helderiano. Por isso a presença do corpo nos poemas de Helder, junto a multas outras perspectivas que ele apresenta e veremos a seguir. contribui para a percepçāo do ser poético, do mundo que o cerca e sua própria contribuição a esse mundo, que são os poemas.

\section{(18) IDEM (17)}

Voltando à enumeraçăo do ser presente neste poema, salientamos palavras como: masculina, mãos, boca, coração, dados, animals - que formam imagens que nos remetem ao mundo interior do poeta.

"Bato a pedra dentro do meu coraçăo" (19) 
juntamente com outras metáforas que nos levam ao mesmo caminho que 6 a busca do eu, do espirito e da eternidade através do que já vimos: a natureza e o ser e mais a solidão e o silênclo.

"As semanas caminham para diante

com um espirito dentro

Mergulham na sua solidāo, e aparecem

batendo contra a luz.

E uma idade com sangue prendendo

as folhas. Terrivel. Mexendo

no lugar do silêncio". (20)

(20)

A solidão do ser vem de encontro com o silêncio da natureza. A natureza e o ser unem-se e formam um mundo à parte, o da criaçăo poética. E o irreal sonhado e não real falado e descrito tal qual é. Tanto é fato. que o poeta se perde na preocupação de eternizar-se e à sua obra volta para dentro de sl e penetra no mundo a seu redor ao mesmo tempo, criando a eterna simbiose: homem - mundo natural. Ou então, pōe-se á parte como algo divino que tudo entende e localiza

"Eu trabalho nas luzes antigas, em frento

das ondas da noite

Estou sentado, $\theta$ falo da ironia de

onde uma rosa se levanta pelo ar". [21]

(21) "

O eu que ao mesmo tempo é dinâmico torna-se estático. No entanto são um só motivo, criam a mesma imagem: a vivência rumo a perpetuação "A Idade é uma vileza espalhada no

léxico". (22)

Com este poema, tentamos inserir definitivamente nosso propósito em dizer que em Herberto Helder há a preocupaçăo fulcral da comunhão: homem (matéria-espírito) e mundo, buscando um só propósito a perpetuaçāo do ser através da criação. E, uma vez o homem conseguindo criar, tornar-se algo divino, onisciente, tme domínio perfeito do que criou, é um deus.

Veremos que estas imagens que levantamos neste poema, no plano onirico, estăo presntes em todos os poemas de Herberto Helder. E Impossivel, óbvio, trazer até este trabalho a análise de todos eles.

No entanto, as imagens se repetem sempre. No mesmo plano da preocupação com o eterno está a valorização da natureza a a problemática das origens e principios; a descoberta e a preocupaçăo com a palavra e a metalinguagem; a economia vocabular versus a vastidāo das imagens, onde a poeta percebe que nẽo 6 ele que opera a palavra $\theta$ sim, ela é que se Impōe ao 
poema. Els o problema do referente: a palavra poética remete a um referente e năo remete a um referente, é um ser e nāo ser. $O$ poeta é o organizador do que sucede trazendo para a Poesia a conciliação desses contrários.

\author{
"Há cidades cor de pérola onde as mulheres \\ existem velozmente. Onde \\ às vezes páram a sāo morosas por dentro. \\ Há cidades absolutas, \\ trabalhadas interiormente pelo pensamento \\ das mulheres. \\ Lugares limpidos e depois noturnos \\ vistos ao alto como um fogo antigo. \\ ou como um fogo juvenil. \\ Vistos fixamente abaixados nas águuas celestes. \\ Emoçōes onde vivo sem orelhas \\ nem dedos. Onde consumo \\ uma amizade bárbara. Um amor \\ levitante. Zona \\ que se refere aos meus dons desconhecidos. \\ Há fervorosas e leves cidades sob os arcos \\ pensadores". [23)
}

(23) POESIA TODA I - Lagar - 1961-1962, "Lugar IV", p. 165.

As imagens são quase que as mesmas do poema anterior. As palavrās se repetem, ora salientando partes do corpo (dedos, orelhas) ora o próprio ser (mulher, espírito, amor), ora a natureza (águas, fogo, lugares). E, acima de tudo, está a constância do poeta no objetivo de atingir a sublimaçāo de algo que se lhe apresenta de forma sobre-humana, que é origem e futuro, busca e encontro. Como exmplo há toda a segunda estância.

Ainda no mundo onírico está presente a palavra em seu caráter inotativo. Vejamos: nestes dois poemas citados, a palavra Idade, por exmplo, está contida em cidade. $O$ ciclo que se fecha em torno dos poemas e das palavras, não pode ser, de forma alguma acidental. Há, sim, a preocupaçāo em não separar. E' uma corrente que arrasta o poeta a construir um mundo näo hermético quanto parece a principio, mas, que busca para si o leitor - a chave da significação da obra. Para quem ela é feita, para que esse mundo é criado a năo ser pelo propósito de haver quem o habilite? Os habitantes do mundo poético nāo sāo as imagens ou as palavras apenas. E sim, o leitor que as bus. ca, encontra-se nelas e nelas permanece.

A obra Helderiana não é hermética como certos criticos apregoam. Muito ao contrário; ela é criada para aqueles que ainda são dualidade, para aqueles que nāo se perderam no concreto. Através da metalinguagem, das ima. gens pseudodifusas e multiplicáveis, do mundo deloucura que ele conhece a denomina 
"Eu durmo no ar dessas cidades femininas cujos espinhos a sangue me Inspiram

o fundo da vida.

Nelas queimo o mês que me pertence

olho minha loucura, escada

sobre escada". (24)

(24) IDEM (23)

nos traz a "palavra povoada", a urgência da comunicabilidade e a prova de que o homem transcende, em forma de poemas.

"E preciso criar palavras, sons, palavras

vivas, obscuras, terriveis.

E preciso criar os mortos pela força

magnética das palavras.

Através da paciência

o esforço do homem tende para a criaçăo

dos mortos". (25)

(25) POESIA TODA II - Humas - 1966 - "Poema Montagem", p. 61.

Esta estrofe é clara, uma proposiçāo é levantada e debatida: 6 preciso criar e criar palavras que se façam realmente ouvir. "Criar" é criar mesmo. Voltamos à pura tautologia mas, que desaparece se, por melo da metátora "criar mortos", criar tomar um sentido que não á mais o do código anterior. Para o poeta, o fato de criar é tão importante que chega a abusar da lógica das coisas: usa o verbo criar em seu sentido próprio (trazer à vida, originar): dá-lhe um sentido de ressurreição quando o une ao complemento - mortos. Por fim, substantiva-o em criaçăo, transformando o que era antes um complemnto direto e um verbo transitivo em adjunto adnominal e locução adjetiva. Em resumo:

1) Criar. E preciso crlar e transformar. De Iníclo, 6 urgente a presença de um emissor (palavras)

2) Uma vez designado esse emissor passa-se à elaboraçāo do código (criar os mortos pela força magnética das palavras)

3) Tendo-se o código, o emlssor busca apenas o aparelho receptor que somos nós leitores porque: "Através da paciência / o esforço do homem tende para / a criaçāo dos mortos" (mensagem).

\section{2 - Da Realidade}

Neste tópico procuraremos salientar o que mais persiste na obra e que revele o quotidiano. Isto năo quer dizer que nos afastaremos do rumo que tomamos em nossa análise até entăo. E, sim, abrangeremos um motivo a mais na obra Helderiana - a colocação do ser pó́tico. $O$ poeta, atra- 
vés ou do sonho ou da realidade circundante, cria focos de transmissōes - poemas - para nos inserir no seu propósito de imortalidade e aceitaçăo. Assim sendo, recolheu palavras, associou imagens várias, inundou-se no tempo e no espaço, caracterizou fatos a momentos de sua e de outras vidas. Enfim, do mundo que o cerca, transportou para dentro de si os elementos únicos que the viessem de encontro ao seu eu para que, depois de sublimados perante e dentro dele mesmo, ressurgissem em forma de comunicabilidade entre ele e esse mesmo mundo-fonte.

E necessário frisar bem esse encontro mundo/poeta/obra. $E_{\text {, dentre }}$ todos os fatores descritos e utilizados pelo poeta está a sua inundação no tempo e no espaço. A obra de Herberto Helder é atemporal e não se coloca. Está em constante ciclo, de onde um equilibrio perdido, se retomado, jamais volta na mesma intensidade. Há sempre um crescente como que para enfatizar o fato da busca, da atemporalidade e das várias dimensōes do ser.

Para confirmarmos o que vimos dizendo não nos detivemos em alguns poemas, apenas. Tentamos visualizar toda a criação Helderiana e concluimos que: em seus primeiros lançamentos (de 1953 a 1966), seus poemas, aparentemente discursivos, longos ou breves, de temas atuais ou evocativos, sempre obedecem a uma certa estrutra elementarmente poética compostos por versos, estrofes, sonoridade, ritmo... Neles, porém, já predominam a imagética e a atemporalidade donde poemas como "Cântico dos Cânticos de Salomão". "Poemas do Velho Tstamento", "Poemas dos Peles -Vermelhas" ("26), a introspecção dos poemas do livro A Colher na Boca,

(26) Sobre easas versōes H. Helder mesmo fala em nota ì p. 209 do vol. I de POESIA TODA : "o meu labor consiste em fazer con que eu próprio ajuste cada vez mais no meu gosto pessoal, o clima ceral do poema já portuguès: a temperatura da imagem. a velocidade do ritmo. a saturaçāo atmosférica do vocábulo, a preasão do adjetivo sobre o substantivo. ..........A regra de ouro é: liberdnde".

e assim por diante. Nesse ritmo sempre crescente, Herberto Helder chega a um ponto tal, que se desvencilha, completamente, tanto da estrutura - como exmplo podem ser citados os poemas em prosa dos livros Retrato em Movimento e Antropofaglas - como da própria coordenaçāo emotiva - poética. Seus temas, agora bem mais variados - "As Maneiras", "Um Deus Llsérgico"... - estão construidos sobre outro equilibrio que é o da infiltraçāo do homem na massa que compōe o mundo e que é formada por ele mesmo. É como se até entāo esse individuo existisse e năo tivesse tomado consciência de sua colocação. Há como que uma descoberta repentina deste fato pelo autor, $\theta$, é deste fato também que partimos para reafirmarmos que na obra Helderiana o ser poético é todo criação e recriação; deslocase no tempo e no espaço, perpetua-se. 
Em seus poemas, Herberto Helder corre no claro e no escuro, na violência e na paz da ternura. Através do abusivo uso de antíteses e metáforas, maneja as palavras e as imagens, por quem se deixa trair abertamente, para que elas sejam o veículo que nos conduza à verdadaira obra poética: mundo/poeta/obra-leitor.

"Transforma-se o amador na coisa
amada" com seu feroz sorriso, os dentes,
as mãos que relampejam no escuro; traz ruido
e silêncio. Traz o barulho das ondas frias
e das ardentes pedras que tem dentro de si
E cobre esse ruído rudimentar com o
assombrado silêncio da sua última vida.
O amador transforma-se de instante para instante
E sente-se o espirito imortal do amor
criando a carne em extremas atmosferas acima
de todas as coisas mortas.

Transforma-se o amador. Corre pelas formas dentro. [27]

(27) POESIA TODA I - A Colher na Boca - 1953-1960, "Transtorma-se o Amador na Coisa Amuda" p. 15.

De inicio, o próprio verbo transformar nos indica o desmembramento, a adimensionalidade $\theta$ a procura. $O$ adjunto adverbial de tempo de instante para instante, concretiza o dinamismo do ser nesse desmembramento. $O$ amador é algo volátll porque não pára, e imortal porque não se coloca, "corre pelas formas dentro" "com o assombrado silêncio da sua última vida". Eis englobado aqui o processo de recriação que demonstra, não só o poder do ser em transformar-se, como também de ser onlpresente.

O "amador", apesar de ser um fato simbólico, é o motivo que alcança o ser fazendo-o tomar consciência de sua condição, posição no cosmos, deveres e possibilidades. $E$ por que "transforma-se o amador na coisa amada"?. Porque não especifica a razäo (ou objetivo) da mensagem: ela 6 geral, para tudo e todos. E a necssidade de reciprocidade de ações entre os seres do cosmos, assim como a aceitação das açōes Individuais $\theta$ a busca da comunicação.

"Ele entra pelos ouvidos, e depois a mulher
que escuta
fica com aquele grito para sempre na cabeça
A arder como o primelro dia do verāo. Ela ouve
a vai-se transformando, enquanto dorme,
naquele grito 
do amador

Depols acorda, e vai, e dá-se ao amador, dá-lhe o grito dele.

E o amador e a coisa amada săo um único

grito anterior de amor". (28)

(28) POESIA TODA 1 - A Colher na Boen - 1953-1960, “Transforma-ke o Amador na Coisa Amada" p. 15 .

AMADOR (emissor)

A COISA AMADA (receptor)

transformar

entrar

bater

grito

\section{MENSAGEM}

Os poemas de Herberto Helder săo elaborados com palavras que determinam objetos concretos, reais: dentes, māos, pedras mulher, cortina, vento, janelas, água, martelo... - em contraposiçāo a outras palavras que remetem ao mundo subjetivo do ser: espírito, amor, amada ilusāo, Deus, divino, beleza, delirio, dons, loucura, amizade... Estes dois grupos de palavras que individualizam dols mundos, concreto e abstrato, väo formar o choque mundo/ser, fazendo com que o ser adquira, assim, uma forma multidimensional no plano da realidade simbólica.

"E as vacas passavam pelos violinos" $[: 9]$

(29) POESIA TODA II - A Miáquín Lírica - 1963. "A menstruaçåo quando na cidado prssava" p. 23.

"E os mortos, nas linhas secas, roendo maçãs vivas, andavam pelo escuro de um nosso pensamento". [30]

(30) POESIA TODA II - A Máquina Lírica, 1963 - "Era uma vez toda a força com a boca nos jornais"' p. 31.

e que nos rmete a um outro mundo onde o tempo nāo se determina. $O$ poeta näo mais, e sim o poema é que vai trazer ao nosso momento, o resultado ser/mundo natural. Säo duas forças que se prendem cada uma com uma carga diversa, a se combinarem.

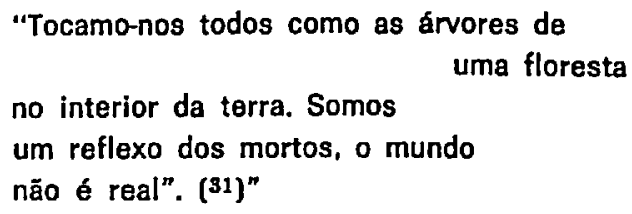


As metáforas usadas pelo poeta vão nos revelando, pouco a pouco, as imagens vislumbradas no mundo poético. O sllêncio e o ruído, a noite e o dia, o amor e o 6dio, o quente e o frio e multo mals antíteses, aparecem num mesmo poema, provando a necessidade da comblnaçāo das diferenças do ser e do mundo.

"E eu desejaria levantar-me levemente sobre as paisagens que se enchem de chuva apalxonada.

Desejaria estar em cima, ao melo da alegria, e abrir os dedos tăo devagar que ninguém sentlsse a melancolia da minha inocêncla.

Tanto desejaria ser destruído por um lento mllagre interior.

Cegar com o rosto contra um ramo abrupto de relâmpagos.

Eu seí. Quero dizer: eu amo essa morte no melo da luz, entre crisálidas $\theta$ gotas, à nolte, de dia quando o mês se extingue num supremo amadurecimento" [32]

(32) POESIA TODA I - Lagar, 1961 - "Lugar VIr", p. 180

Herberto Helder nos traz em sua linguagem mergulhada no experimental

"A maçã precipltada, os Incêndios da noite, a neve forte:

e a rude beleza da cabeça". ( $\left.{ }^{33}\right)$

(33) POEsia tODA II - Cinco Cançōes Lacanares, 1968 - "Canção Despovoada" p. 176. e no mistico

"Para onde arresta Deus os dons que me obscurecem? VI as catedrais florescerem como roseiras divagando as suas altas rosas." (84)

(36) POESIA TODA II - Retrato em Morimento, 1961-1968 - "Estudio V" - p. 129. a procura do inexplorado, do insólito, a diversidade de mundos que se compõem para formar seu universo poético. Joga-se nos labirintos do espírlto humano a na vivêncla telúrica do homem indo de encontro no natural bruto (árvores, pedras, fogo, terra...) como numa ânsia de recuperar o que já está lapidado pela civilização. Helder natural: a comunicaçăo visceral entre o homem e sua condiçäo primelre, desde há muito bloqueada pelos excessos do refinamento civilizado e disclplinador dos Instintos. 
“E preciso falar baixo no sítio da primavera

junto à terra nocturna. Junto à terra transfigurada

Tudo ouve as minhas palavras talvez irremediáveis

Infatigável perfume se acrescenta nos jacintos

fogo sem fim circunda suas raizes leves". ( $\left.{ }^{35}\right]$

(36) POESIA TODA I - A Colher na Boca, 1953-1960 - "As Musas Cegas" vi p. 106

"Fora, os corpos genuinos e inalteráveis

do nosso amor,

os rios, a grande paz exterior das coisas,

as folhas dormindo o silêncio

- a hora teatral da posse" [36]

(36) POESIA TODA I A Colher na Boes, 1953-1960 - “o poems" I p. 38

Porque é a mais alta forma de revelação do humano, Herberto Helder faz da linguagem sua paixão e nela se entranha, fazendo de cada poema uma nova geração; construindo espaços além da vida e da morte; glorificando e corporificando o que existe de perdurável no mundo anterior de que somos herdeiros, inovando-o.

\section{$v$ - CONCLUSAO}

Herberto Helder tem, indubitavelmente, uma consciēncia criadora lúcida, projetada no conhecido reinventando-o desde a origem, através da palavra

"Posso falar às mãos.

Posso extremamente falar as palavras.

$E$ nas palavras que as barcas gemem.

Nelas se estabelece o rio". ( $\left.{ }^{3 i}\right]$

(37) POESIA TODA I - Poemacto. 1961 "Poemacto v" p. 112

Nessa reinvenção do conhecido Helder realiza experiências intransferiveis e decisivas do ser, com a através da palavra, para que os ciclos da vida se cumpram e perdurem. Daí, sua revelaçăo sempre camuflada pelas metáforas e antiteses, mil vezes multiplicadas em cada poema, de sua ânsia de transformar-se em um semi-deus da poesia e através dela ser eterno. As. sim. estaria eternizando o poder criador humano de uma supra-realidade, pela palavra; e, unindo-as chegaria (chega...?!) ao ponto de dar a nós, leitores, de hoje e de sempre, os valores essenciais do homem que perduram imutáveis, redescobrindo-o sempre como único inventor e construtor da aventura.

Faremos nossas as palavras de Fernando Guimarães acerca da funçāo da obra Helderiana: "o livro não cabe no apertado de suas palavras. Estas, podem reservar-nos o equivoco de se solidificarem num conjunto de deslgnaçōes, na chave com que julgamos abrir o seu enigma 
. (a obra) Atenta à violência da linguagem, à sua total disponibilidade, a palavra e, também, ao ato da palavra, ela soube partir sempre à descoberta de novos caminhos: $O$ que $e$ próprio da grande poesia". (38)

(38) COLOQUio - Letras - Notas e comentīios acercu da nublicaçäo de POESIA TODA : de Herberto Helcier - p. 73 , n. $15-9 / 73$.

Herberto Helder ainda é uma dualidade. Porque como ser massificedo, jamais poderia ter-se transposto além da barreira do tempo e de espaço, jamais nos teria feito parar para circular no domínio da realidade concreta/ comum que nos situa no dia-a-dia, e, ali permanecermos. Atualmente, o homem passou a construir tudo de forma altamente concreta, passando a crer somente naquilo que ele possa apalpar ou dissecar. A poesia não the fugiu a esta forma de construção. Helder ainda não se deixou levar por esta corrente, muito ao contrário. seus poemas parecem ser centro de emanaçōes, e, ao mesmo tempo, receptividade de todas as influências do Cosmos.

A obra de Herberto Helder está. Cabe a cada leitor decifrá-la...

\section{B I B L I}

1) AREAL, Antonio Santiago - Estrututa do Sentido Antecipado por Análige e Deflniçäo de Poesia, Portugália Ed., Lisboa, 1958

2) BoUso, Curlos - Teoria de Expression Poélica - Editorial - Madrid - 1973

3) BeLo, Ruy - N $\mathrm{N}$ Senda da Poesia - "Poesia e Arte Poética em Herberto Helder".

4) COIIEN, Jean - Estrutura da Linkumgem Poética - Ed. Cultrix

5) Declo, Joāo - Introdugāo ao Estudo da Pocsia de Herberto Heldex - Revista Alfa - n." 17, Marllia, 1971

6) DUfrenne, Mikel - 0 Poético - Ed. Globo, P. Alegre, 1969

7) Guiraud, Pierre - A Estilisticn - Ed. Mestre Jou, S. Paulo.

8) HeLder, Herberto - Poesin Toda - Plátano Editora, Lísboa

9) KAYSER, Wolfgang - Anilisc e Interpretação da Obra Literária - vol. I, Arménio Amado, Editor. Sucessor, Coimbra.

10) LePECKI, Maria Lúcia - "O Off́cio de Dizer" - O Estalo de São Paulo - Suplemento Literärio $-31 / 12 / 73$.

11) LePEckl, Maria Lúcia - "Sobre a Poesla de Herberto Helder" - Revista Vozes, n. 4, Hio de Janeiro

12) MoISts, Massaud - Gula Prótleo de Análise Literária - Ed. Cultrix, S. Paulo.

13) MARQUES, Oswaldino - Ensaios Escolhidan - (Teoria e Critica Literárias). Civilização Brabileira.

14) MENDonÇA, Fernando - A Literatura Portuguesa no Século $\mathrm{XX}$ - Hicitec, $\mathrm{S.}$ Paulo, 1973.

15) JAkoBsoN, Roman - Lingalistica - Poética - Cinema - Ed. Perspectiva. S. Pado

16) Vozes - Revista de Cultura - n.0 7 - 1972. 